\title{
Rainwater Harvesting for Agriculture and Domestic Supply in Enugu North Agricultural Zone, Nigeria
}

\author{
Ajayi, A. R. and C. C. Ugwu \\ Department of Agricultural Extension \\ University of Nigeria, Nsukka \\ Email: adefioye2003@yahoo.com
}

\begin{abstract}
The turning point for water resources development and management policy in Nigeria could be traced as far back as 1960 after the severe drought of the 1950s. In year 2000, the federal government formulated a new National Water Supply and Sanitation Policy. The study was designed to determine whether or not, a national policy on domestic rainwater harvesting is entrenched in the national water supply and sanitation policy. A case study was carried out in Enugu north agricultural zone of Enugu State. Data for the study were collected from 70 respondents through the use of a structured interview schedule. Frequency distribution, percentage and mean statistic were used in the analysis of the data. The findings revealed that there was an absence of national, state and local government's policy on domestic rainwater harvesting for agriculture and domestic supply in the study area unlike what is obtainable in other countries such as China, Brazil, Zimbabwe and India. It was recommended that the National Water Supply and Sanitation Policy in Nigeria should be reviewed to accommodate domestic rain water harvesting for agriculture and domestic supply.
\end{abstract}

\subsection{INTRODUCTION}

Water is the most precious natural resource and something that most people take for granted. Many are now increasingly becoming aware of the importance of water to their survival and its limited supply especially in the dry continents of the world (www.sustainable.com.au). It is a precious natural resource, vital for life, development and the environment. It can be a matter of life and death, depending on how it occurs and how it is managed. When it is too much or too little, it can bring destruction, misery or death. Irrespective of how it occurs, if properly managed, it can be an instrument for economic survival and growth. It can be an instrument for poverty alleviation in that it makes many people have access to safe water and sanitation, while at the same time, it brings prosperity to all as a result of it economic value (UN-WAER/AFRICE, 2004). However, when it is inadequate in either quantity or quality, it can be a limiting factor in poverty alleviation and economic recovery, resulting in poor health and low productivity, food insecurity and constrained economic development (Gbadegesin and Olorunfemi, 2003). 
Domestic rainwater harvesting (DRWH) is a way of capturing rainwater when it rains. The captured water is stored above ground or underground and it is used later (www.akash-ganga-rwh.com). According to Gould (1992), DRWH is a technology (e.g. rooftop, land surface, storage thank, rainwtercontainers) used mostly by rural dwellers for collecting and storing water from rooftops, the land surface or rock catchments using common water collecting materials such as jars and pots as well as more complex materials such as underground check dams. The techniques usually found in Asia and Africa arose from practices employed by ancient civilizations within these regions and still serves as a major source of drinking water supply in rural areas. Among the known common DRWH techniques, the bamboo roofs are the least suitable because of possible health hazards. Similarly, roofs with metallic paints or other coatings are not recommended as they may impart tastes or colour to the collected water. Roof catchments should also be cleaned regularly to remove dust, leaves and bird droppings so as to maintain the quality of the product water (UNEP, 1982).

Rainwater harvesting provides drinking water and irrigation water, increases groundwater recharge, checks storm water discharges, urban floods and overloading of sewage treatment plants (www. india.org). Rainwater harvesting can save money. If one lives where annual rainfall averages one foot, one can save money by collecting and storing rainwater and using it to irrigate trees, shrubs and lawns; cooking and laundry (http:// aggie-horticulture.tamu.edu/mastergd.mg.html). From China to Peru, Niger to Palestine, Afghanistan to Mexico and in many African countries, the effort to access water of adequate quality and quantity absorbs a major part of the daily official working hours and capital significantly, with serious security implications. In many of these countries, rainwater harvesting has helped in reducing the unnecessary tension due to water shortage. Millions of people, mainly women, harvest, collect and rainwater for the drinking, cooking and washing needs of their families (http://www.irinnews.org/indepthmain.aspx).

In many rural areas of different countries in the world, government agencies, non-governmental agencies, churches and community organizations are getting more and more involved in the concepts of DRWH and its efficient utilization for water security and sustainability currently, there are moves within non-governmental organisation(NGOs) and within government agencies to make rainwater harvesting more popular as a way of gaining water for domestic and agricultural use. The technique has particular relevance where ground water is not easily accessible (Morgan, 1998).

In Zimbabwe, rainwater harvesting has a valid application in the arid, high rainfall, rural and urban areas. In the drier parts of the country, sufficient water can be harvested at clinics to cater for the water needs of the clinics and its visitors throughout the year. The use of rainwater harvesting tank is being promoted by several NGOs both at the family level and at schools and clinics. An important use of rainwater harvesting may be in schools without adequate supplies of fresh water nearby, where the area of the roof is large and the potential for catching large amount of water is great (Morgan, 1998).

In India, there is a National Water Harvesters Network (NWHN). This is an organization that is saddled with the responsibilities of addressing and highlighting the local issues and the traditional systems relating to water harvesting to further the cause of community based water management (www.cseindia.org). In North eastern 
Brazil, rural workers, unions and NGOs play an important role in the organization, the carrying out and financing of rainwater projects. Throughout Brazil's semi - arid region, these workers and other organizations are trying to convince politicians at a local and a state level of the possibility of sustainable development of the region, excluding the necessity for big irrigation projects from rivers or groundwater (Gnadlinger, 1999; World Bank, 1993; Smet, 2003).

\subsection{Problem of the study}

In many countries of the world, the sustainability of household water security through domesticated rainwater harvesting has attracted the attentions of the federal and local governments, NGOs and other legitimate and well-recognised agencies such as rural community organisations. For instance, in Sri Lanka, with the acceptance by the government of DRWH as a water supply option and with the formation of the Sri Lanka rainwater harvesting forum, the concept is gaining wide acceptance in many parts of the country (Ariyabandu, 1998). In 1996 and 1998, many new national rainwater associations were formed in Germany and Uganda, respectively (Terry 2000).

In countries such as Germany, Sri Lanka, China and Colombo, universities have been involved in domestic rainwater harvesting researches (Ariyabandu, 1998; Terry, 2000; Qiang and Yuanhong, 2000, and Heijnen and Mansur, 1998). Different international developmental organisations such as the World Bank, UNICEF, UNEP and UNESCO etc. have also been found to be involved in designing policies that did promote the concept of DRWH as a major strategy for sustaining water and food production security in most of the rural areas of the world (www.wsp.org).

Enugu north agricultural zone experiences short period of rainy season (and the rains always come very late) and long period of dry season. Rivers, streams, ponds, pipe borne water and wells are not easily accessible. The primary sources of water to both Nsukka-urban and rural dwellers are the University of Nigeria, Nsukka campus water plant and the domestic harvested water during the short rainy season. Domestic rainwater harvesting is a common phenomenon in the area and it forms the major sustainable water security to the farm families. The harvested rainwater has been source of water supply to the farm families who carry out their farming activities in the dry season. Such farming activities include Nsukka yellow pepper production, solanum production, vegetable (Ugu) production, etc. (Ugwu, 2007).

The arduous collection condition of rainwater drastically limits water consumption, especially, in the rural areas. The harvested rainwater is more available to the richer members of the poor communities. During this annual long dry season, children, youths and adults are obliged to walk long distance places sourcing water supplies. This results to increase in household expenditures, decline in household income, loss of assets, savings and a rise in a number of dependants (relying on a small number of productive family members); high rate of absenteeism from work and drop out from schools, especially, among girls. The time for agricultural and other socio- economic activities is wasted in searching for water. Often, women would take over six hours to bring home 50 litres of dirty water that would not be enough for the family. This might result to disability of some family members due to water-related diseases which cause the people to withdraw from potential supply of labour in farm and non farm economic activities (Ugwu, 2007). 
Having established the existence and usefulness of DRWH in rural areas of many countries of the world, and the involvement of governments, NGOs, community-based organisations and various international developmental organisations in their promotion as a basic strategy for sustaining water security, one would like to find out how DRWH activities are being carried out in Enugu north agricultural zone. The study was also designed to determine whether or not, a national policy on domestic rain water harvesting is entrenched in the national water supply and sanitation policy in the state.

\subsection{Purpose of the study}

The purpose of this study is to determine the DRWH activities for agriculture and domestic supply among farm-families in Enugu north agricultural zone and at the same, find out whether or not, a national policy on DRWH is entrenched in the national water supply and sanitation policy in the state. Specially, the study was designed to:

(1) determine the DRWH methods/techniques being used by farm-families in Nsukka LGA of Enugu state;

(2) determine households decision-making role in DRWH in Nsukka LGA of Enugu state;

(3) determine the uses and perceived advantages of using harvested domestic rainwater by farm-families in Nsukka LGA;

(4) determine the role of government, NGOs, Churches, University, Research institutes and local organisations/associations in DRWH in Nsukka LGA of Enugu state.

\subsection{METHODOLOGY}

Enugu north agricultural zone is made up of six LGAs, namely: Udenu, Nsukka, Igbo-Eze North, Igbo-Eze South, Uzo-uwani and Isi-Uzo. Out of these six LGAs, Nsukka LGA was purposively selected for the study(because of pronounced water shortage in the area). It is bounded by Isi-Uzo LGA in the East and in the West by Igbo-Etiti as well as in the North and South by Uzo-Uwani and Igbo-Eze LGAs. The 1992 census indicated that Nsukka Local Government Area has a population of 309633(Federal Republic of Nigeria, 2007) persons. The population for the study consisted of the farm-families in Nsukka LGA. (Ugwu, 2007). Nsukka LGA is made up of 16 communities ( Ihe-Owere, Ibagwa Ani, Okwutu, Alo-Uno, Edem, Obimo, Nru, Umakashi, Okpuje, Okpaligbo, Ede Obala, Lejja, Opi, Obukpa and Mkpunano) and out of these, 6 communities were purposively selected due to their involvement in many agricultural activities and water problem. The communities included Edem, Nru, Ihe-Owerre, Opi, Mkpunano and Obukpa (Ugwu, 2007). In each of the communities, two villages were selected (from the list of villages) through simple random sampling technique. From the two villages selected in Edem, a total of 15 farm - families were selected (From the list of available farm-families) using simple random sampling technique. The same number of farm-families was sampled from Ihe-Owere. From each of the remaining four communities (Nru, Mkpunano, Opi and Obukpa) 10 farm-families were also selected through simple random sampling technique (see Table 2). Therefore, the sample size for the study was 70 farmfamilies. 
TABLE 2: The sample composition

\begin{tabular}{lccccccc}
\hline $\begin{array}{c}\text { Name of } \\
\text { communities }\end{array}$ & Edem & $\begin{array}{c}\text { Ihe- } \\
\text { Owere }\end{array}$ & Nru & Mkpunano & Opi & Obukpa & Total \\
\hline $\begin{array}{l}\text { Number of } \\
\text { villages selected }\end{array}$ & 2 & 2 & 2 & 2 & 2 & 2 & 12 \\
$\begin{array}{l}\text { Total number of } \\
\text { farm-families }\end{array}$ & 15 & 15 & 10 & 10 & 10 & 10 & 70 \\
& & & & & & &
\end{tabular}

Data for the study were collected from the respondents through the use of well structured interview schedule. The instrument was divided onto 5 sections on the basis of the objectives. Data were analysed by using frequency distribution, percentage and mean statistic

\subsection{RESULTS AND DISCUSSION}

\subsection{Methods used in DRWH}

Table 3 indicates that all (100.0\%) the respondents were using roof top collection and a large number of them $(54.3 \%)$ did captured ground water. The table further shows that only very few of them (7.1\%) made use of polythene sheets. The findings imply that the major methods used by the farm families in the study area were the roof top collection and capturing of ground water. The polythene sheets were used occasionally, especially, when the family lives in a thatched house. These methods are also found in other countries of the world (Ariyabandu, 1998).

TABLE 3: Percentage distribution of respondents based on the various methods used in domestic rainwater harvesting $(n=70)$

\begin{tabular}{|l|c|c|}
\hline \multicolumn{1}{|c|}{ Variable } & (N0) & (\%) \\
\hline Roof top collection & 70 & 100.00 \\
\hline Capturing of groundwater & 38 & 54.3 \\
\hline Use of Polythene sheets & 5 & 7.1 \\
\hline
\end{tabular}

Source: Field survey, 2007

${ }^{*}$ Multiple response

\subsection{Households decision making role in domestic rainwater harvesting}

Table 4 indicates that the husbands played the roles of provision of money for the construction $(98.6 \%)$, purchasing of the needed materials from the market $(45.7 \%)$ and repairing of damaged roof, containers and tanks (50.0\%). The roles of initiating the domestic rainwater harvesting $(78.6 \%)$, treating of water with alum $(62.9 \%)$, and purchasing of water tanks $(52.9 \%)$ rested on the wives.

Also, from Table 4, it is evident that the children played vital roles more than their parents in such areas as harvesting of water(77.1), cleaning of containers $(91.4 \%)$, drawing of water from the well $(71.4 \%)$ and cleaning of the roof, gutter and 
Journal of Agricultural Extension

Vol. 12 (1) June, 2008

containers at the on-set of rainy seasons $(91.4 \%)$. The implication of these findings is that any extension programme mapped out to improve DRWH activities in the area should involve the husbands, wives and children.

TABLE 4: Percentage distribution of respondents based on the various household decision making roles in DRWH $(n=70)$

\begin{tabular}{|c|c|c|c|}
\hline \multirow[b]{2}{*}{ Variable } & \multicolumn{3}{|c|}{ Household decision making roles } \\
\hline & Husbands (\%) & Wives (\%) & $\begin{array}{l}\text { Children } \\
(\%)^{*}\end{array}$ \\
\hline Initiator of DRWH & 20.0 & 78.6 & 1.4 \\
\hline $\begin{array}{l}\text { Provision of money for the } \\
\text { construction }\end{array}$ & 98.0 & 1.4 & 0.0 \\
\hline $\begin{array}{l}\text { Purchasing of the needed } \\
\text { material from the market }\end{array}$ & 45.7 & 48.6 & 5.7 \\
\hline Purchasing of water tank & 40.0 & 52.9 & 7.1 \\
\hline $\begin{array}{l}\text { Digging of the underground } \\
\text { well/tank }\end{array}$ & 14.3 & 0.0 & 5.7 \\
\hline $\begin{array}{l}\text { Construction of the gutter round } \\
\text { the edge of the roof }\end{array}$ & 15.7 & 0.0 & 4.3 \\
\hline Cleaning of container & 1.4 & 7.1 & 91.1 \\
\hline $\begin{array}{l}\text { Repairing of damaged roof, } \\
\text { container and tank }\end{array}$ & 50.0 & 41.5 & 7.1 \\
\hline $\begin{array}{l}\text { At the on-set of rainy seasons, } \\
\text { who cleans the roof, gutter and } \\
\text { containers }\end{array}$ & 4.3 & 4.3 & 91.4 \\
\hline Who draws water from the well & 1.4 & 27.1 & 71.4 \\
\hline $\begin{array}{l}\text { Who treats the water with } \\
\text { chemical(Alum) }\end{array}$ & 12.9 & 62.9 & 24.3 \\
\hline
\end{tabular}

Source: Field survey, 2007

*Multiple response

\subsection{The uses of harvested rainwater}

According to Table 5, harvested rainwater was used primarily for cooking food $(100.0 \%)$, bathing $(100.0 \%)$, molding of blocks $(100.0 \%)$, livestock production $(100.0 \%)$, washing of household utensils $(100.0 \%)$, building of houses $(98.6 \%)$, laundry work $(95.7 \%)$, drinking $(90.05)$, dry season crop production $(80.0 \%)$, growing of seedlings in the nursery $(54.3 \%)$, watering of ornamental flowers $(30.0 \%)$ and flushing of toilet $(28.6 \%)$. This implies that the harvested rainwater was used for different purposes by the farm-families and this is in agreement with what is 
obtainable in other countries of the world (Morgan, 1998; Gnadlinger, 1999; Smet, 2003).

TABLE 5: Percentage distribution of respondents based on various uses of harvested rainwater $(n=70)$

\begin{tabular}{lcc}
\hline \multicolumn{1}{c}{ Uses of harvested domestic rainwater } & (N0) & $(\mathbf{4})^{*}$ \\
\hline For cooking food & 70 & 100.0 \\
For bathing & 70 & 100.0 \\
For flushing toilet & 20 & 28.6 \\
Moudling of blocks & 70 & 100.0 \\
For building of household & 69 & 98.6 \\
Growing of seedlings in the nursery & 38 & 54.3 \\
For drinking & 63 & 90.0 \\
Used for laundry work & 67 & 95.7 \\
For dry season crop production & 56 & 80.0 \\
For watering ornamental flowers & 21 & 30.0 \\
Livestock production & 70 & 100.0 \\
Washing of household utensils & 70 & 100.0 \\
For income generation by selling & 2 & 2.9 \\
For fishery production & 6 & 8.6
\end{tabular}

Source: Field Survey, 2007

* Harvested domestic rainwater was used for various purposes

\subsection{The perceived advantages of using harvested domestic rainwater by farm-families}

The respondents strongly agreed that DRWH helped to reduce family expenses on water $(\bar{X}=4.0)$ and the time loss in searching for water $\bar{X}=4.0)(($ Table 6) The table also shows that the respondents agreed that DRWH helped in checking run-off water $(\bar{X}=3.0)$, providing food and health security for the household members $(\bar{X}=$ $3.0)$, improving the quality of life of the households $(\bar{X}=3.03)$ and providing additional time for children to carryout their studies $(\bar{X}=3.33)$. Readily availability of water in the rural area reduces the distance walked to fetch water and improves children's attendance at school (Ajayi and Ogba, 2006). 
Journal of Agricultural Extension

Vol. 12 (1) June, 2008

TABLE 6: Mean score distribution of respondents based on the perceived advantages of using domestic harvested rainwater by farm families $(n=70)$

\begin{tabular}{|c|c|c|c|c|c|c|}
\hline Perceived advantage & $\begin{array}{l}\text { SA } \\
(4)\end{array}$ & $A(3)$ & $D(2)$ & $\begin{array}{l}\text { SD } \\
(1)\end{array}$ & $\begin{array}{l}\text { (Total } \\
\text { score) }\end{array}$ & $\begin{array}{l}\text { Mean } \\
\text { Score } \\
(\bar{X})\end{array}$ \\
\hline $\begin{array}{l}\text { It reduces family expenses on } \\
\text { water }\end{array}$ & 288 & 39 & 0 & 0 & 267 & 4.0 \\
\hline $\begin{array}{l}\text { Reduces time loss in searching } \\
\text { for water }\end{array}$ & 188 & 69 & 0 & 0 & 257 & 4.0 \\
\hline It helps in checking run-off water & 28 & 174 & 10 & 0 & 212 & 3.0 \\
\hline $\begin{array}{l}\text { It provides food and health } \\
\text { security for the household } \\
\text { members }\end{array}$ & 28 & 162 & 18 & 0 & 208 & 3.0 \\
\hline $\begin{array}{l}\text { It improves the quality of life of } \\
\text { the household }\end{array}$ & 40 & 105 & 50 & 0 & 195 & 3.0 \\
\hline $\begin{array}{l}\text { It provides additional time for } \\
\text { children to carryout their studies }\end{array}$ & 36 & 144 & 24 & 1 & 205 & 3.0 \\
\hline
\end{tabular}

Source: Field Survey, 2007

\section{Supportive Role Expectation of the Governmental and Non-governmental Agencies for Effective DRWH}

According to Table 7, the governments (federal, state and local governments) is expected to perform the roles of formulating policies concerning planning, implementing and operation of DRWH supply and sanitation; funding of DRWH projects; addressing local issues arising from DRWH; designing and implementing campaign strategy for effective and healthy harvesting and use of rainwater, and environmental sanitation education; and promotion of DRWH materials (e.g. tanks). Unfortunately, none of these roles was found to have been performed by the Nigerian governments unlike what is in practice in other countries such as Sri-Lanka, Peru India, China, Mexico Brazil and Zimbabwe (www.wsp.org).

Although the 2000 National Water Supply and Sanitation Policy (WSSP) in Nigeria stated that government should sponsor capital investment for rural water supply, DRWH projects were not entrenched and the level of provision of water in the rural areas is still very low (Gbadegesin and Olorunfemi, 2007). If local conditions and demand are taken into account in the planning, financing, implementing and operation of water supply and sanitation systems, the sense of ownership and willingness of communities to share in the cost and operations / maintenance will be greatly enhance, thereby increasing the sustainability of the systems (Gbadegesin and Olorunfemi, 2007). 
In other countries of the world (e.g. Brazil, Afghanistan, Mexico, Niger, Palestine, Zimbabwe, Sri Lanka, Germany, China, Australia, and Colombo), various agencies, apart from their governments, were found to be actively involved in funding of the DRWH projects; addressing local issues arising from DRWH; providing campaign for effective and healthy harvesting and use of rainwater and environmental sanitation education; promoting DRWH materials (e.g. tanks); and carrying out advocacy (Morgan, 1998; Gnadlinger, 1999; Agwu, 2007). However, the contrary to these is obtainable in Nigeria as evident in Table 7. 
Journal of Agricultural Extension

Vol. 12 (1) June, 2008

TABLE 7: Supportive Role Expectation of the Governmental and Non-governmental Agencies for Effective DRWH in Nigeria

\begin{tabular}{|c|c|c|c|c|c|c|}
\hline \multirow{2}{*}{$\begin{array}{l}\text { Government and Non-Governmental } \\
\text { Agency }\end{array}$} & \multicolumn{6}{|c|}{ The Supportive Role Expectation of the Agency } \\
\hline & $\begin{array}{c}\text { Policy } \\
\text { Concerning } \\
\text { planning, } \\
\text { implementing } \\
\text { and operation } \\
\text { of DRWH } \\
\text { supply and } \\
\text { sanitation } \\
\end{array}$ & $\begin{array}{c}\text { Funding of } \\
\text { DRWH } \\
\text { project }\end{array}$ & $\begin{array}{l}\text { Addressing } \\
\text { Local Issues } \\
\text { arising from } \\
\text { DRWH. }\end{array}$ & $\begin{array}{l}\text { Design and } \\
\text { implementation of } \\
\text { campaign for } \\
\text { effective and healthy } \\
\text { harvesting and use of } \\
\text { rainwater and } \\
\text { environmental } \\
\text { sanitation education }\end{array}$ & $\begin{array}{c}\text { Promotion } \\
\text { of DRWH } \\
\text { materials } \\
\text { (tank) }\end{array}$ & $\begin{array}{c}\text { Advocacy } \\
\text { (calling the } \\
\text { attention of both } \\
\text { the Local and } \\
\text { State } \\
\text { Government }\end{array}$ \\
\hline $\begin{array}{l}\text { Federal Government (Federal Ministry } \\
\text { of Water Resources) }\end{array}$ & 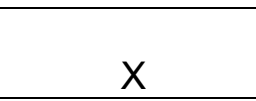 & $\mathrm{X}$ & & 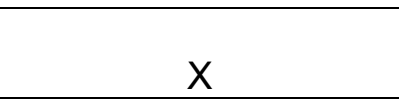 & & \\
\hline State/LGA Water Agencies & $\mathrm{X}$ & $\mathrm{X}$ & $\mathrm{X}$ & $\mathrm{X}$ & $\mathrm{X}$ & \\
\hline UNICEF & & $\mathrm{X}$ & & & $\mathrm{X}$ & $\mathrm{X}$ \\
\hline Ministry of Health & $\mathrm{X}$ & $\mathrm{X}$ & & $\mathrm{X}$ & $\mathrm{X}$ & \\
\hline $\mathrm{FAO}$ & & $\mathrm{X}$ & & & $\mathrm{X}$ & $\mathrm{X}$ \\
\hline WHO & & $\mathrm{X}$ & & & & \\
\hline Word Bank & & $\mathrm{X}$ & & & $\mathrm{X}$ & \\
\hline UNEP & & $\mathrm{X}$ & & & & \\
\hline Churches & & $\mathrm{X}$ & $\mathrm{X}$ & $\mathrm{X}$ & & \\
\hline Schools & & $\mathrm{X}$ & $\mathrm{X}$ & $\mathrm{X}$ & & \\
\hline ADP & & $\mathrm{X}$ & $\mathrm{X}$ & $\mathrm{X}$ & $\mathrm{X}$ & $\mathrm{X}$ \\
\hline Rainwater Harvesting Research Group & & $\mathrm{X}$ & $\mathrm{X}$ & $\mathrm{X}$ & $\mathrm{X}$ & $\mathrm{X}$ \\
\hline Local Associations & & $\mathrm{X}$ & $\mathrm{X}$ & $\mathrm{X}$ & $\mathrm{X}$ & $\mathrm{X}$ \\
\hline University & $\mathrm{X}$ & $\mathrm{X}$ & $\mathrm{X}$ & $\mathrm{X}$ & $\mathrm{X}$ & $\mathrm{X}$ \\
\hline
\end{tabular}

$X=$ Expected supportive role not performed. 


\section{CONCLUSION}

Based on the findings of this study, the following conclusions were made:

1. The major methods being used by the farm-families in harvesting rain water were roof top collection and capturing of the land surface water

2. The husbands, wives and children were all involved in household decision making roles in DRWH.

3. The rain water harvested had varying advantages with varying uses to the farm families for agriculture and domestic supplies..

4. There were expected policy and supportive roles needed for the effectiveness of DRWH from the governments and other agencies which were yet to be carried out.

\section{RECOMMENDATION}

1) It was recommended that the National Water Supply and Sanitation policy of Nigeria should be reviewed to accommodate domestic rain water harvesting domestic and agriculture supply.

2) Both governmental and non-governmental agencies should be actively involved in funding of the DRWH projects in the study area. Besides, they should be adequately and effectively involved in addressing local issues arising from DRWH and providing campaign for enlightenment, healthy harvesting, proper storage and good environmental education relating to the use of harvested rain water.

3) The non-governmental agencies (e.g. UNDP, IFAD, UNICEF and churches) should perform the role of advocacy relating to increasing the level of water supply in the rural area, especially, through DRWH.

\section{References}

Ajayi A. R. and I. O. Ogba (2006). Agricultural and socio-economic impact of water aid programme among farm-families in Igede land of Benue State, Nigeria. Proceedings of the $11^{\text {th }}$ Annual National Conference of AESON, pp. 25-37.

Ariyabandu, R, de S. et al (2000). Water Resources and Development of RWH in Sri Linka. Waterlines International Journal of Appropriate Technologies for Water Supply and Sanitation, vol. 18 No 3.

Ariyabandu, R.de S. (1998). Study of Existing Rainwater Harvesting Technology, Report, Lanka Rainwater Harvesting Forum, Sn Lanka.

Basics of RWH. Newspaper Reports on RWH Activity Across India, March/April, 2006. retrieved from: $h$ ttp://akash-ganga-rhw.com.

Gbadegesin, N and Oorunfemi, F. (2003). Assessment of Rural Water Supply Management in Selected Rural Areas of Oyo State, Nigeria. ATPS Working Paper Series No. 49.

Gnadlinger, J.(1999). Rainwater Catchment in Brazil's Rural Semi-arid Tropics: A Gross roots Approach. $9^{\text {th }}$ International Rainwater Catchment Systems Conference at Petrolina, Brazil. 
Gould, J. (2000). Rainwater Catchment Systems: Reflections and Prospects. Waterlines International Journal of Appropriate Technologies for Water Supply and Sanitation, vol 18, No. 3.

Gould, J.E. (1992). Rainwater Catchment Systems for Household Water Supply, Environmental Sanitation Reviews, No. 32, ENSIC, Asian Institute of Technology, Bangkok.

http://www.cseindia.org

http://www.irinnews.or/indepthmain.aspx

http://www.sustainable.com.au

Humanitarian Impact of he Global Water Crisis. Retrieved from:

http://www.irinnews.org/indepth main.aspx.

http://www.wsp.org

Heijnen, $\mathrm{H}$ and Mansur, U. (1998). Rainwater Harvesting in the Community Water Supply and Sanitation Project. Proc. Symp on Rainwater Harvesting for Water Security, Our Engineering Technology, vol. 2, Open University, Colombo.

Morgan, P. (1998). A low Cost Gutter Techniques Using Waterproof Shade Cloth for use in Rainwater Harvesting.

Smet, J. (2003). Domestic Rainwater Harvesting.

Terry, T. (2000). Where is Roofwater Harvesting Going? Waterlines International Journal of Appropriate Technologies for Water Supply and Sanitation, vol 18, No.3.

Ugwu, C.C. (2007). Domestic Rainwater Harvesting for Agriculture and Supply among Farm Families in Nsukka Local Government Area of Enugu State. B.Agic Project, Dewpartment of Agricultural Extension, University of Nigeria, Nsukka.

United Nations Environment Programme (1982). Rain and Storm Water Harvesting in Rural Areas, Tycooly International Publishing Ltd, Dublin.

World Bank (1993). Water Resource Management. A World Bank Policy Paper, Washington. 